\title{
Cultivation of black truffle to promote reforestation and land-use stability
}

\author{
J.A. BONET, C.R. FISCHER*, C. COLINAS \\ Centre Tecnològic Forestal de Catalunya, Pujada del Seminari s/n, E-25280 Solsona, Spain
}

(Accepted 8 November 2005)

\begin{abstract}
Cultivation of black truffle, Tuber melanosporum Vitt., has become an important agricultural alternative in rural Mediterranean regions due to its success in relatively harsh conditions, its high market value and diminishing production in natural areas. In addition, truffle cultivation requires relatively low agricultural inputs, promotes reforestation and economic restoration of rural lands and land-use stability. However, there remain major issues regarding the management practices to ensure successful black truffle production. We therefore conducted an experiment to evaluate 3 levels of irrigation based on monthly water deficit and the effects of currently applied weed control systems and fertilization. Treatment effects were evaluated by examining the mycorrhizal status of out-planted 1-yr-old Quercus ilex L. seedlings and seedling growth parameters after 18 months in 3 distinct experimental truffle plantations located in the foothills of the Spanish Pyrenees. We found that replacing one-half of the water deficit of the driest month (moderate irrigation) promoted the proliferation of T. melanosporum mycorrhizae, while high irrigation reduced fine root production and truffle mycorrhizae. Glyphosate weed control improved seedling survival by up to $16 \%$ over control seedlings without jeopardizing truffle mycorrhizae in the first year. Fertilization did not improve seedling growth or influence its mycorrhizal status. We describe the persistent relationship between this ectomycorrhizal fungus and $Q$. ilex by quantifying old and new mycorrhizae and we discuss the ecological implications of the symbiosis.
\end{abstract}

agricultural alternative / ectomycorrhiza / Quercus ilex / water deficit

\section{INTRODUCTION}

The black Perigord truffle (Tuber melanosporum Vitt.) has attracted increasing interest as an agricultural alternative in marginal lands and depressed farming regions (Bencivenga et al., 1983; Romieu and Tabouret, 1995) due to its success in relatively harsh conditions, its declining production in Europe and its high market value. This hypogeous ascomycete, which produces mature ascocarps or fruit bodies (truffles) in late autumn and winter, grows in ectomycorrhizal symbiosis with hazelnut trees and several oak species in Mediterranean conditions. It is native to the calcareous regions primarily of France, Italy and Spain and is found on well-drained, open forest or farmlands with high $\mathrm{pH}$, warm summer temperatures and relatively low, but well-partitioned annual rainfall (Delmas and Poitou, 1974).

Annual black truffle production during the last 100 years has dropped from approximately 1000 to 50 tons in France (Callot, 1999), where conditions in historically productive truffle sites have been altered due to climatic and anthropogenic changes. Annual fresh weight productions from plantations vary with reports of $50 \mathrm{~kg} / \mathrm{ha}$ from well-managed 13-14-yr-old plantations in Italy (Bencivenga and Di Massimo, 2000), $45 \mathrm{~kg} / \mathrm{ha}$ reported from irrigated plantations in Spain (Carbajo, 2000) and $15-50 \mathrm{~kg} / \mathrm{ha}$ with exceptional yields of up to $110 \mathrm{~kg} / \mathrm{ha}$ in 14-yr-old plantations in France (Chevalier and Frochot, 1997). Average retail prices in Europe range from 300-450 euros $/ \mathrm{kg}$ fresh weight (Olivier, 2000) although summer droughts in Europe in 2003 and 2004 have resulted in low truffle production and higher prices of up to 700-900 euros/kg for high quality truffles.

Cultivation in orchards began intensively with the development of nursery techniques to induce T. melanosporum ectomycorrhiza formation in receptive host seedlings (Chevalier and Grente, 1978). Productive truffle orchards in France, Italy and Spain presently provide rural landowners with an alternative to agricultural subsidies, promote restoration of abandoned cereal lands and require relatively low agricultural inputs (Samils et al., 2003). More recently, truffle plantations have been installed in New Zealand, Australia, Israel and North America with production reported from New Zealand and North America (Lefevre and Hall, 2001) and from Australia in 2005 (Malajczuk, pers. comm.). Occasionally plantations begin producing black truffles within 3 years after establishment but typically production begins $6-10$ years after inoculated seedlings

* Corresponding author: christine.fischer@ctfc.es 
have been planted. Although cost-benefit analyses differ widely among countries (Bonet and Colinas, 2001), results from successful plantations have stimulated a rising international interest where adequate or amendable ecological conditions exist. Truffle cultivation requires long-term investments and promotes stability in the agricultural and socio-economic environments.

Mass production of Tuber-colonized host seedlings has represented the most important progress in truffle cultivation for the past 30 years. Cultivation techniques have, unfortunately, not progressed accordingly (Chevalier, 1998). The heterogeneity of yields is problematic and experimental studies that examine summer moisture requirements, tilling methods and timing, irrigation and fertilization treatments and long-term effects of herbicides and pesticides are lacking (Chevalier, 1999).

Management of irrigation has proven to be critical to the maintenance of, and increase in, black truffle yields in mature plantations, particularly in regions subject to drought (Le Tacon et al., 1982; Carbajo, 1999; Bencivenga and Di Massimo, 2000). Irrigation is also advised during the first two years to support seedling establishment and to maintain T. melanosporum colonization levels (Giraud and Pigeon, 1993).

Greenhouse and field observations reflect both beneficial as well as detrimental effects of irrigation according to the amount of water applied, water retention properties of the soil and presence of fluorescent Pseudomonas bacteria (Olivier et al., 1996). Based on pot experiments using Corylus avellana $\mathrm{L}$. as the host tree, Mamoun and Olivier (1990) concluded that moderate irrigation induces good root development and the expansion of T. melanosporum mycorrhizae, but high levels of irrigation appear to be unfavorable, as this may promote root colonization by other soil-borne fungi including $T$. brumale Vitt., a less desirable black truffle species (Mamoun and Olivier, 1993). Further work is needed to test their results with oak seedlings and in field conditions.

During the establishment phase the optimal amount of irrigation depends on local climatic conditions and is aimed at reducing extreme water stress while simultaneously avoiding constant soil humidity, which can favor competing mycorrhizal fungi. Standard recommendations of $30-60 \mathrm{~L} / \mathrm{m}^{2}$ per month at 7-10-day intervals are given in the management of plantations (Giraud and Pigeon, 1993; Sáez and De Miguel, 1995). Ricard et al. (2003) suggest 10-20 L/plant applied infrequently.

Soil tilling to a maximum depth of 5 to $10 \mathrm{~cm}$ to control weeds and to aerate the ground is a widespread procedure in truffle cultivation. However, no tillage of soil, according to the Tanguy method (Sourzat, 1999), and weed control using herbicides (Verlhac et al., 1990) are also recommended. Ricard et al. (2003) suggest herbicide applications and/or mechanical tilling at superficial depths during the establishment years to eliminate competing vegetation and to promote breakdown of organic matter.

Fertilization has had opposing views but is another common practice in truffle orchards. Periodic fertilization is recommended to improve the growth of seedlings without harming mycorrhizae by applying an equilibrated combination of phosphorus and nitrogen (Chevalier and Desmas, 1976; Chevalier and Poitou, 1989; Dupré et al., 1982). Commercial fertilizers specific to truffle orchards are sold in France and Spain, but the results are irregular. More recent technical guides (Sourzat,
2002; Reyna, 2000) advise the site-specific correction of minerals, calcium and organic material based on soil analyses. In an analysis of factors that influence the onset of black truffle production in a $Q$. ilex plantation, Shaw et al. (1996) found the critical factor correlated with black truffle production to be stem diameter of the host tree. If adequate nutrition improves tree growth while the mycorrhizal level is not affected, earlier and/or better yields may be achieved.

The aims of the present research are to evaluate the effects of (1) irrigation calculated as a function of water deficit, (2) weed control and (3) fertilization in young truffle plantations by examining $T$. melanosporum mycorrhizae development of inoculated Quercus ilex seedlings and growth responses after 18 months in the field. We chose to work with $Q$. ilex because it has become the most important oak species for truffle plantations in Spain and in other drought-prone Mediterranean climates.

\section{MATERIALS AND METHODS}

\subsection{Experimental design and study sites}

This is a factorial study with irrigation, weed control and fertilization as factors, with three levels each for a total of 27 treatment combinations. Each treatment was randomly assigned to an experimental unit of 10 inoculated seedlings, arranged in a 6-m square. Each experimental unit was surrounded by a 6-meter border defined by a single row of non-inoculated seedlings to control for border effects. There were 12 meters of border between each treatment (experimental unit). The 27 treatments were replicated in 3 blocks, each at different locations (Tab. I) in the eastern pre-Pyrenees (Solsonès, Lleida, Spain). None of these sites had tree cover and Locality 2 was dominated by grasses and common weeds after 15 years' fallow following potato and oat cultivation. There was a total of 810 inoculated seedlings out-planted in this study.

\subsection{Plants}

Q. ilex seedlings (1-yr-old) inoculated with T. melanosporum were purchased from "Cultivos Forestales" (Torre de las Arcas, Teruel, Spain), a commercial forestry nursery.

Plant quality was evaluated according to the methodology described by Fischer and Colinas (1996). Twelve plants were randomly selected from the inoculated lot and all root systems were cleaned of soil substrate for quantification of total roottips, T. melanosporum mycorrhizae and mycorrhizae of other fungi before planting in December 1997. Non-inoculated $Q$. ilex seedlings were purchased from the same nursery, and a sub-sample of these was also examined microscopically to confirm the absence of $T$. melanosporum mycorrhizae in seedlings destined for out-planting in the borders surrounding each experimental unit.

\subsection{Treatments}

\subsubsection{Irrigation}

Irrigation treatments aimed to test the compensation for the water deficit of the month with the highest water deficit of the 
Table I. Site and soil characteristics for each experimental plantation.

\begin{tabular}{lccc}
\hline & Locality 1 & Locality 2 & Locality 3 \\
\hline Altitude $(\mathrm{m})$ & 620 & 1200 & 875 \\
Pre-plantation crop & Grassland & Abandoned & Cereal \\
$\mathrm{pH}$ & 8.4 & 8.0 & 8.2 \\
Organic material $(\%)$ & 1.0 & 9.0 & 5.4 \\
Calcium carbonate $(\%)$ & 39 & 3 & 27 \\
Nitrogen $($ Kjeldahl $)(\%)$ & 0.06 & 0.43 & 0.33 \\
Phosphorus $($ Olsen $)(\mathrm{ppm})$ & 12 & 8 & 11 \\
Potassium $(\%$ of potassium oxide $)$ & 57 & 306 & 213 \\
Exchangeable magnesium $(\%)$ & 111 & 455 & 120 \\
Coarse sand $(0.2<\mathrm{D}<2 \mathrm{~mm})(\%)$ & 10.7 & 14.3 & 14.4 \\
Fine sand $(0.05<\mathrm{D}<0.2 \mathrm{~mm})(\%)$ & 53.0 & 27.5 & 26.9 \\
Coarse silt $(0.02<\mathrm{D}<0.05 \mathrm{~mm})(\%)$ & 11.8 & 15.4 & 13.8 \\
Fine silt $(0.002<\mathrm{D}<0.02 \mathrm{~mm})(\%)$ & 14.2 & 28.6 & 23.1 \\
Clay $(\mathrm{D}<0.002 \mathrm{~mm})(\%)$ & 10.3 & 14.2 & 21.8 \\
USDA Classification & Sandy loam & Loam & Loam \\
\hline
\end{tabular}

year, July for this region, during the following month, August in this case. Water deficit was determined by estimating water needs as a function of evapotranspiration (ETP) and rainfall following Thornwaite and Mather (1955) as adapted by Gandullo (1985).

$$
\begin{aligned}
& \mathrm{ETPj}=16 \mathrm{fj}(10 \mathrm{tj} / \mathrm{l})^{\wedge} \text { alpha } \\
& \mathrm{ETPj}=\text { Evapotranspiration of month } \mathrm{j}
\end{aligned}
$$

$\mathrm{fj}=$ mean monthly sunlight hours compared with 1 month of 12 hours of sunlight for 30 days

$\mathrm{t}_{\mathrm{j}}=$ mean temperature for month $\mathrm{j}$

$\mathrm{I}=$ Index of annual heat $=$ Sum of $(\mathrm{tj} / 5)^{\wedge}(1.514)$ of every month for 12 months of 1 year

Alpha $=0.000000675 \mathrm{I}^{\wedge} 3-0.0000771 \mathrm{I}^{\wedge} 2+0.01792 \mathrm{I}+$ 0.49239 .

Applying this formula, we obtained the ETP for each month and each locality. Water deficit was calculated as the difference between the monthly rainfall and ETP. According to this method, the water deficit for the driest month obtained for all three localities during 1998 was the same: $110 \mathrm{~L} / \mathrm{m}^{2}$. Three levels of summer irrigation were tested: no irrigation, moderate level of irrigation and high level of irrigation. The moderate level of irrigation $\left(55 \mathrm{~L} / \mathrm{m}^{2}\right)$ represents compensating for half the water deficit, and the high irrigation level $\left(110 \mathrm{~L} / \mathrm{m}^{2}\right)$ represents totally compensating for the water deficit of the month with the greatest water deficit of the year. These irrigations were divided into 2 doses applied during the following month.

\subsubsection{Weed control}

Weed control was tested at three levels: no treatment (control), mechanical soil tilling between the rows with the tines set to 8-10 cm deep, and the application of a commercial glyphosate-based systemic herbicide (Roundup, Monsanto, St. Louis, $\mathrm{MO}, \mathrm{USA}$ ) at $6 \mathrm{~L} / \mathrm{ha}$. A $2 \%$ dilution was used according to the manufacturer's recommendations. These treatments were applied in May 1998.

\subsubsection{Fertilization}

High amounts of fertilizers are not recommended for truffle production and fertilizer residues from previous crops may be detrimental to successful truffle cultivation (Olivier, 2000). We chose a single application of a mild, foliar fertilizer, Proferfol (12-7-7, Productos Foliares S.L., Zaragoza, Spain). Concentrations in the foliar fertilizer were: $12 \% \mathrm{w} / \mathrm{w}$ total nitrogen $(\mathrm{N})$ (8\% urea, $1 \%$ nitric acid and 3\% ammonia); $7 \%$ w/w phosphoric anhydride $\left(\mathrm{P}_{2} \mathrm{O}_{5}\right)$ soluble in water; $7 \%$ w/w of potassium oxide $\left(\mathrm{K}_{2} \mathrm{O}\right)$ soluble in water. Other elements present at low concentrations in the foliar fertilizer were: $0.05 \%$ boron $(\mathrm{B})$, $0.05 \%$ copper $(\mathrm{Cu}), 0.1 \%$ iron $(\mathrm{Fe}), 0.1 \%$ magnesium $(\mathrm{Mg})$, $0.05 \%$ manganese $(\mathrm{Mn})$ and $0.05 \%$ zinc $(\mathrm{Zn})$. Control, $7 \mathrm{cc} / \mathrm{L}$ and $12 \mathrm{cc} / \mathrm{L}$ of water were the three levels of application. The fertilizer was manually applied to individual seedlings with a mist solution, saturating all the leaves with care to avoid surrounding vegetation. Control seedlings were saturated with water. Fertilizer was applied in early July.

\subsection{Data collection}

After 18 months in the field (June, 1999), seedling mortality (percent of dead plants in each experimental unit) and height (average of surviving plants in each experimental unit) were measured.

One plant out of 10 from each experimental unit was randomly selected for belowground observation and measurements. A total of 81 plants was carefully dug out from the field and taken to the laboratory where they were cleaned, eliminating soil particles without damaging the root-tips. Taproot length was measured first before separating the root system into two parts: (1) plug - the roots developed in the nursery, and (2) new root growth - the roots growing outside the remnants of nursery potting substrate. Total length of new root growth (including the taproot) was estimated using the grid intersect method (Newman, 1966; Marsh and Marsh, 1971). 
Table II. Mean mycorrhizal status for pre-plantation nursery seedlings and for seedling plugs after 18 months in the field. Numbers in brackets are $95 \%$ Confidence Intervals. Results represent pooled data across all treatments.

\begin{tabular}{lccc}
\hline & $\begin{array}{c}\text { New T. melanosporum } \\
\text { root-tips }\end{array}$ & $\begin{array}{c}\text { Old } \text { T. melanosporum } \\
\text { root-tips }\end{array}$ & Total root-tips \\
\hline $\begin{array}{l}\text { Pre- } \\
\text { plantation }\end{array}$ & 1406 & 0 & 2638 \\
seedling & $(1157-1655)$ & & $(2378-2897)$ \\
Seedling & 343 & 337 & 1132 \\
Plug & $(282-403)$ & $(287-386)$ & $(983-1281)$ \\
\hline
\end{tabular}

Seedling mycorrhizal colonization status, separating new from old T. melanosporum tips and non-T. melanosporum mycorrhizae, was quantified using the grid procedure (Fischer and Colinas, 1996). We separated new tips from old tips to observe the persistence of the mycorrhizae following out-planting stresses and by treatments during the first 18 months. We defined new and old according to color, morphology and mantle characteristics as follows.

T. melanosporum mycorrhizae were identified following the description of Rauscher et al. (1995). New black truffle mycorrhizae, both ramified and non-ramified, were beige to brown with lighter tones in the root apex and were swollen compared with nonmycorrhizal tips. Cystidia with perpendicularly-oriented branching were observed. A superficial plectenchymatous mantle was present and the pseudoparenchymatous epidermoid mantle was well developed with multiple layers. The old truffle mycorrhizae, as differentiated from the new, appeared often as ramified, branching grape-like clusters and were dark brown to black. In the most advanced condition they had lost their swollen morphology, appearing deflated, dry and wrinkled. The epidermoid mantle was clearly developed but with fewer mantle layers present, and the outer plectenchymatous mantle layer was lacking. Characteristic cystidia were rare in the old T. melanosporum tips.

Total number of root-tips, non-mycorrhizal root-tips, total mycorrhizae of T. melanosporum differentiating new from old tips, and number of contaminants (mycorrhizae of fungi other than $T$. melanosporum) were obtained for the plug and for the new root growth.

\subsection{Statistical analysis}

Analysis of variance was performed to determine treatment effects and the means were separated using Fischer's Protected LSD test at $P<0.05$ (Ramsey and Schafer, 1996). Some variables were transformed to meet the assumptions of ANOVA. In these cases treatment means obtained from transformed data were back-transformed to the original scale and are reported as medians (Weisberg, 1980).

\section{RESULTS AND DISCUSSION}

\subsection{Seedling mycorrhizal status}

In the plants sampled prior to out-planting a mean of 1406 root-tips/plant $(53.3 \%$ of the total) were colonized by
Table III. Mean seedling height, taproot length and total root length of new root growth for seedlings removed from plantations after 18 months. Numbers in brackets are 95\% Confidence Intervals. Results represent pooled data across all treatments.

\begin{tabular}{lc}
\hline Growth Variable & Measurement \\
\hline Seedling height & $18 \mathrm{~cm}(17.0-19.1)$ \\
Taproot length & $43.3 \mathrm{~cm}(41.3-45.2)$ \\
Total root length of new root growth & $203 \mathrm{~cm}(178.9-227.5)$ \\
\hline
\end{tabular}

T. melanosporum (Tab. II). No other mycorrhiza was found in the nursery seedlings. After 18 months in the field there were no significant interactions among treatment effects.

\subsection{Irrigation}

Irrigation treatments did not have significant effects on plant height or taproot length, but influenced $(P=0.06)$ the ratio of shoot height to taproot length. Under the high irrigation treatment, the taproot grew deeper relative to the shoot height. Irrigation did not affect the total length of new root growth. Mean total new root growth in the field was $203 \mathrm{~cm}$ (Tab. III).

In the plug, no significant differences in mycorrhizal status were detected among treatments (Tab. II). Non-T. melanosporum mycorrhizae were observed in only one of the 81 seedling plugs after 18 months in the field.

In the new root growth we observed differences in plant mycorrhizal status in response to irrigation treatments (Fig. 1). The control seedlings and those treated with the moderate irrigation level maintained higher numbers of old T. melanosporum-colonized root-tips than seedlings treated with high irrigation.

This negative influence of the high irrigation was further evidenced in the lower number of T. melanosporum mycorrhizae per meter of new root growth compared with those with the lower irrigation treatment (Fig. 2). Seedlings with the higher level of irrigation also had lower total fine root production per meter of new root growth than seedlings from the other 2 irrigation treatments.

Irrigation did not influence colonization by contaminating fungi. Contaminants were very rare throughout the experiment. Only 5 seedlings out of the 81 studied had any contaminants, and in these 5 seedlings, they averaged only $3.7 \%$ of their total root-tips. Two of the 5 seedlings had Cenococcum geophilum Fr. mycorrhizae, and the other fungi were not identifiable based on the morphologic characteristics of the mycorrhizae.

We attribute this low percentage of contamination during these 18 months primarily to the lack of ectomycorrhizal inoculum present in the plantation soils, which were all previously dominated by communities of plants (cereals, grasses, potatoes and common weeds) which form vesicular-arbuscular mycorrhizae or are non-mycorrhizal.

The irrigation treatments, applied in 2 doses during the late summer drought period, did not reduce mortality or improve seedling height, although irrigation had a significant influence on the mycorrhizal status. Our results substantiate that moderate irrigation (consisting of compensating for one-half the water deficit of the driest month) is preferable to compensation 


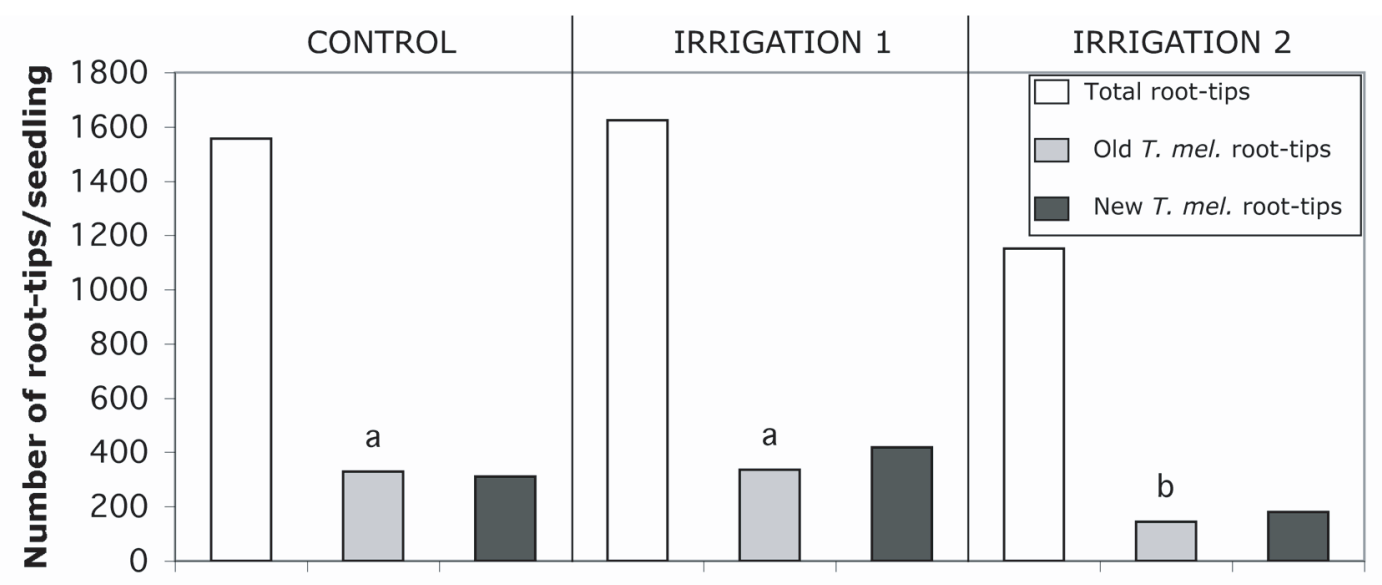

Figure 1. Median number of total root-tips, old T. melanosporum root-tips, and new T. melanosporum root-tips per seedling in the new root growth according to irrigation treatment. Differences among irrigation levels were detected at $P=0.05$ for old T. melanosporum root-tips and $P=0.07$ for new T. melanosporum root-tips. Total root-tips were not significantly different among treatments. Control = no irrigation; Irrigation $1=$ moderate level irrigation treatment and Irrigation $2=$ high level irrigation treatment.

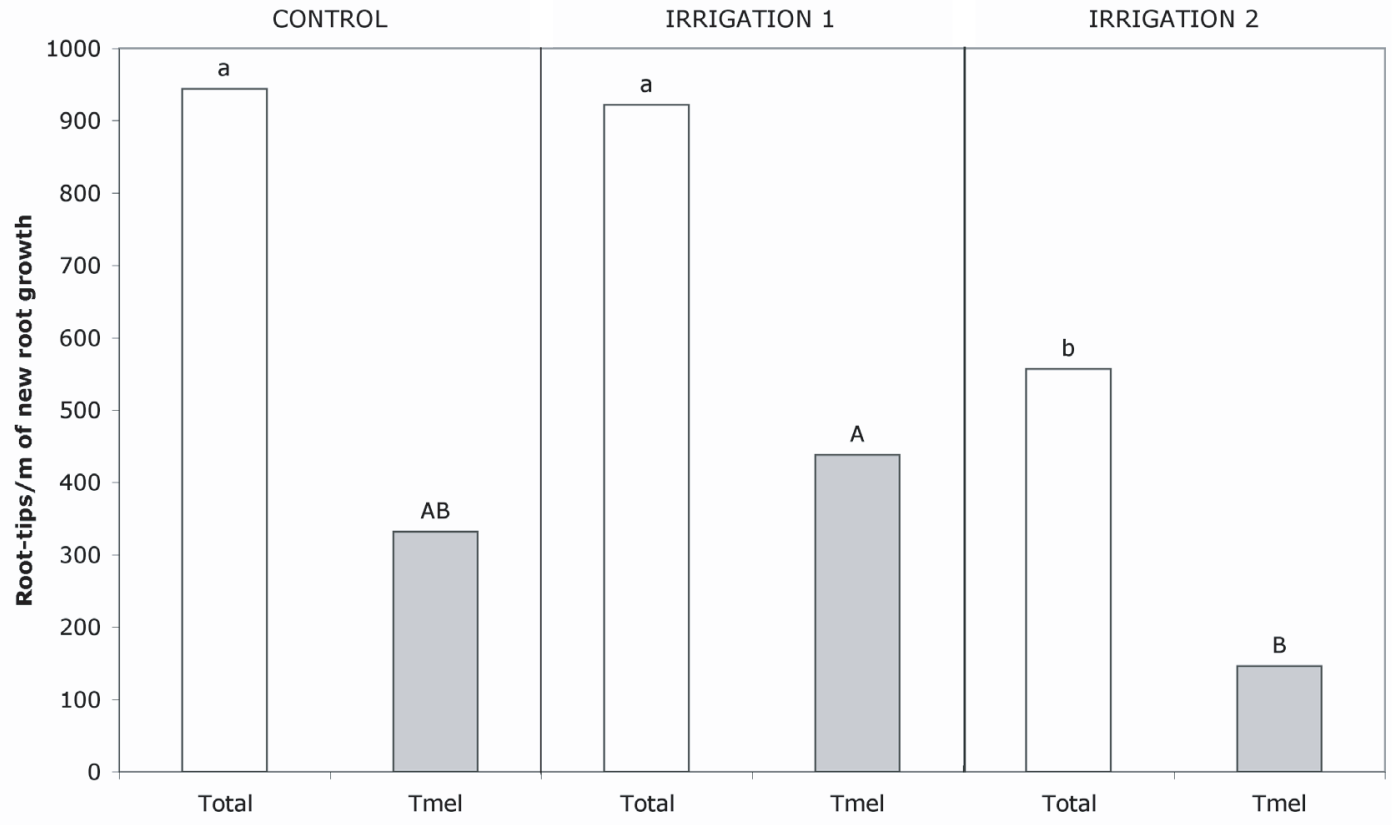

Figure 2. Median number of total fine root-tips (Total) and T. melanosporum root-tips (Tmel) per meter of new root growth according to irrigation treatment. Differences among irrigation levels were detected at $P=0.02$ for both variables. Values in each column followed by the same letter do not differ significantly $(P=0.05)$ according to the LSD test. Control $=$ no irrigation; Irrigation $1=$ moderate level irrigation treatment and Irrigation 2 = high level irrigation treatment.

for the total water deficit for the proliferation of T. melanosporum mycorrhizae with $Q$. ilex in the year following plantation. At this time, the emphasis is on providing belowground conditions that favor maintenance of the fungal-plant symbiosis.

An understanding of the life strategy of this Mediterranean evergreen oak adapted to water-limited habitats helps to explain the new root growth patterns we observed. At the early stages of development $Q$. ilex seedlings rapidly develop a deep taproot (Canadell et al., 1999), allocating initial resources to establishing a link with a deep water source, and secondly, to the development of lateral and trophic roots. Under moderate water stress $Q$. ilex maintains higher stomatal conductance for longer periods than shallow-rooted Mediterranean woody species (Acherar and Rambal, 1992). T. melanosporum colonization of 


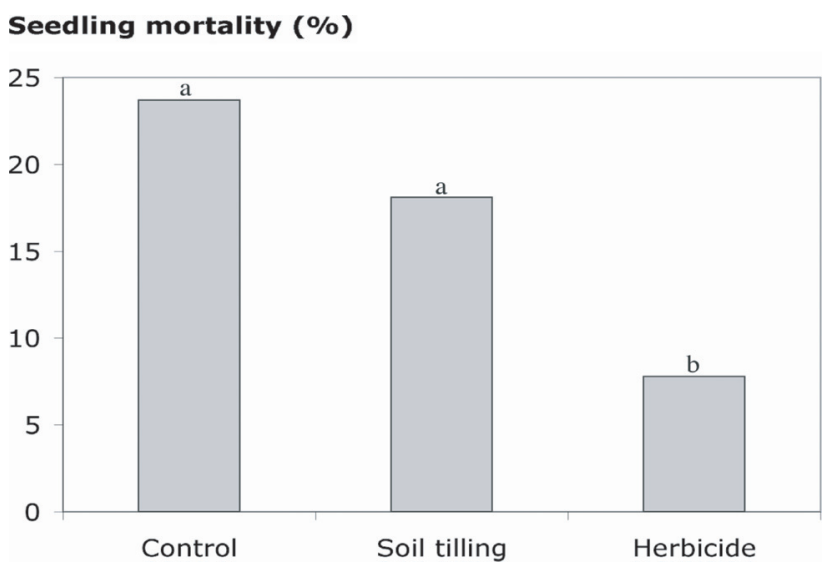

Figure 3. Percent of seedling mortality in response to weed control treatment. Differences between levels of weed control were detected at $P=0.002$. Values in each column followed by the same letter do not differ significantly $(P=0.05)$ according to the LSD test.

$Q$. ilex has been shown to reduce root hydraulic conductance, which is offset by increased fine root biomass, more efficient vertical water transport to leaves and higher $\mathrm{CO}_{2}$ fixation (Nardini et al., 2000). These observations, taken into account with our findings of higher levels of $T$. melanosporum colonization with lower soil water availability (control and moderate irrigation treatments), suggest an interactive survival mechanism between the plant and symbiotic fungus to adapt to the harsh soil and climatic environments where they have evolved. Our seedlings given the high irrigation treatment allocated more resources to taproot development, with relatively less for fine root production, while seedlings given no irrigation or moderate irrigation allocated more resources to developing the mycorrhizae, which can help compensate for the lower water availability.

\subsection{Weed control}

Weed control had a significant effect on seedling mortality. Herbicide treatment reduced mortality over control and soil tilling $(P=0.002)$ (Fig. 3). These results are not homogeneous in all the localities. Mortality was highest in locality 1 (28.4\% versus $18.1 \%$ and $5.3 \%$ in localities 2 and 3 , respectively). The application of herbicide did not have a significant effect on seedling growth responses (Tab. III).

Weed control is considered a necessary management tool for truffle plantations (Sourzat, 1997), and here we observed its importance for seedling survival in the first year. The herbicide treatment reduced mortality more than tilling without impacting the number of black truffle mycorrhizae. However, chemical inputs may not be desirable and more frequent tilling than tested here may be necessary to provide the same level of weed control. Unfortunately, we do not have data on long-term effects of herbicide use in truffle plantations. Ricard et al. (2003) warn that long-term use may adversely affect soil fauna and microflora with degradation of soil structure.

Elimination of plant competition in the establishment phase significantly reduced mortality, probably by reducing compe- tition for water in early summer. As the spring of 1998 was relatively dry, the timing of weed control was particularly important. The differences that we observed in percent of mortality by locality may be attributed to site-specific soil characteristics and their corresponding water-holding capacities. In this study locality 1 , with a higher soil sand content and potentially lower water-holding capacity than the other 2 localities (Tab. I), had the highest reduction of seedling mortality in response to weed control.

\subsection{Fertilization}

We did not observe any treatment effect of fertilization on survival, growth or mycorrhizal status of these seedlings in the first 18 months in the field. We know of no studies which provide conclusive data supporting fertilization in either mature or establishment phases. A meta-analysis of vesicular-arbuscular and ecto-mycorrhizal responses to fertilization shows decreases in percent of mycorrhization of $32 \%$ with nitrogen and $47 \%$ with phosphorus (Treseder, 2004), suggesting caution and site-specific soil analysis prior to applications of fertilizers to truffle plantations.

\subsection{Out-planting stress}

The number of T. melanosporum mycorrhizae at planting (plug) drops in all seedlings independently of the treatment after 18 months in the field (Tab. II). The number of nonmycorrhizal root-tips also does, and to a larger extent, such that the percent of T. melanosporum mycorrhizae after 18 months in the field actually increases. We separated old from new tips to look at the capacity of $T$. melanosporum to thrive after transplant shock and under various cultivation treatments. Seedlings from all treatments had older blackened $T$. melanosporum root-tips from which new mycorrhizae developed, evidence of the perennial nature of this symbiosis. T. melanosporum is not easily displaced in the establishment phase given that soil and climatic conditions meet the ecological parameters observed for truffleproducing areas.

\section{CONCLUSION}

We have tested a method for quantifying irrigation needs for truffle plantations in the establishment phase based on actual water deficits and have determined that the compensation of half the water deficit of the driest month promotes maintenance of the fungal-plant symbiosis. Standard recommended irrigation rates given in $\mathrm{L} / \mathrm{m}^{2}$ cannot easily incorporate variations in plant water status based on site-specific conditions, annual rainfall, temperature or evapotranspiration rates. We propose the use of calculating water needs as a function of water deficit in order to promote a rational method that can be adjusted to different sites and conditions. We anticipate that seedling water stress could vary depending on host species, plantation density, or water-holding capacity of a specific soil, but hopefully by approaching the problem from the point of water deficit we can establish a foundation for further experimentation and discussion of an applied science. 
Effective weed control is required for seedling survival at this stage. Further work is needed to evaluate the timing and frequency of mechanical tilling methods as well as the effects of long-term herbicide use. Nutritional support and improvement of host tree growth remain intriguing problems for successful truffle cultivation and the onset of truffle production. Future experimental questions that focus on the multiple factors involved in $Q$. ilex growth and carbon storage patterns as well as the nutritional strategies of and trade-offs with this ectomycorrhizal fungus may provide more insight into appropriate fertilization and cultivation success.

Acknowledgements: This project was supported in part by the European Union LIFE environmental grant No. LIFE96/ENV/E/512 and by the Department of Environment of the Generalitat de Catalunya. We wish to thank the plantation-owners for their collaboration, providing land and assistance with maintaining the plantations.

\section{REFERENCES}

Acherar M., Rambal S. (1992) Comparative water relations of four Mediterranean oak species, Vegetatio 99/100, 177-184.

Bencivenga M., Granetti B., Mincigrucci G. (1983) Tartufaie artificiali nei terreni marginali, LÍnformatore Agrario, Verona 39, 27449-27459.

Bencivenga M., Di Massimo G. (2000) Risultati produttivi di tartufaie coltivate di Tuber melanosporum Vitt. in Umbria, Micologia Italiana $2,38-44$.

Bonet J.A., Colinas C. (2001) Cultivo de Tuber melanosporum Vitt. Condiciones y rentabilidad, Forestalia 5, 38-45.

Callot G. (1999) La Truffe, La Terre, La Vie, Institut National de la Recherche Agronomique, INRA Ed., Paris.

Canadell J., Djema A., López B., Lloret F., Sabaté S., Siscart D., Gracia C.A. (1999) Structure and dynamics of the root system, in: Rodà F., Retana J., Gracia C.A., Bellot J. (Eds.), Ecology of Mediterranean Evergreen Oak Forests, Ecological Studies 137, Springer-Verlag, Berlin, pp. 47-59.

Carbajo P. (1999) Gestión de una gran plantación de trufa, in: Colinas C., Fischer C. (Eds.), Cultivo de hongos comestibles micorrícicos, Publ. Univ. de Lleida, Lleida, Spain.

Carbajo P. (2000) Plantación de Arotz-Catesa, in: Jornadas de Truficultura, 26-28 Oct. 2002, Castellón, Spain.

Chevalier G. (1998) The truffle cultivation in France: assessment of the situation after 25 years of intensive use of mycorrhizal seedlings, Proceedings of the Second International Conference on Mycorrhiza, 5-10 July, 1998, Uppsala, p. 43.

Chevalier G. (1999) Du congrès de Spoleto à celui d'Aix-en-Provence : les avancées en matière de recherches sur la truffe et la trufficulture en France, Actes du V $\mathrm{V}^{\mathrm{e}}$ Congrès International : Science et culture de la truffe, 4-6 mars 1998, Aix-en-Provence, pp. 11-15.

Chevalier G., Desmas Ch. (1976) Mycorrhization par Tuber melanosporum de plants de Quercus pubescens en milieu fortement fertilisé, Ann. Phytopathol. 9, 93.

Chevalier G., Grente J. (1978) Application pratique de la symbiose ectomycorrhizienne : production à grande échelle de plants mycorrhizés par la truffe (Tuber melanosporum Vitt.), Mushroom Sci. 10, 483505 .

Chevalier G., Poitou N. (1989) Study of important factors affecting the mycorrhizal development of the truffle fungus in the field using plants inoculated in nurseries, Agric. Ecosyt. Environ. 28, 75-77.
Chevalier G., Frochot H. (1997) La maîtrise de la culture de la truffe, in: Champignons et mycorrhizes en forêt, Rev. Forest. Française 49, 201-213.

Delmas J., Poitou N. (1974) La truffe et ses exigences écologiques, Pépiniéristes Hort. Maraîchers 144, 33-39.

Dupré Ch., Chevalier G., Morizet J., Leblevenec L. (1982) Influence de l'azote et du phosphore sur la mycorhization de Quercus pubescens Willd. par Tuber melanosporum Vitt. en conditions contrôlées, Les mycorrhizes : Biologie et utilisation, Les colloques de l'INRA 13, $147-153$.

Fischer C., Colinas C. (1996) Methodology for the certification of Quercus ilex seedlings inoculated with Tuber melanosporum for commercial application, First International Conference on Mycorrhiza, Aug. 4-9, 1996, Berkeley, CA.

Gandullo J.M. (1985) Ecología Vegetal. Ed. Fundación Conde del Valle de Salazar, ETSIM, Madrid.

Giraud M., Pigeon M. (1993) Truffe, Les conditions de la réussite, InfosCTIFL 96, 25-28.

Lefevre C.K., Hall I.R. (2001) Status of truffle cultivation: a global perspective, Mehlenbacher S.A. (Ed.), Acta Hort. 556, 513-520.

Le Tacon F., Delmas J., Gleyze R., Bouchard D. (1982) Influence du régime hydrique du sol et de la fertilisation sur la fructification de la truffe noire du Périgord (Tuber melanosporum Vitt.) dans le sudest de la France, Acta Oecol. 3, 291-306.

Malajczuk N. (2005) pers. comm., PO Box 1920, Subiaco,Western Australia 6008 .

Mamoun M., Olivier J.M. (1990) Dynamique des populations fongiques et bactériennes de la rhizosphère des noisetiers truffiers. III. Effet du régime hydrique sur la mycorrhization et la micoflore associée, Agronomie 10, 77-84.

Mamoun M., Olivier J.M. (1993) Competition between Tuber melanosporum and other ectomycorrhizal fungi under two irrigation regimes, Plant Soil 149, 211-218.

Marsh B., Marsh B. (1971) Measurement of length in random arrangements of lines, J. Appl. Ecol. 8, 265-267.

Newman E.I. (1966) A method of estimating the total length of root in a sample, J. Appl. Ecol. 3, 139-145.

Nardini A., Salleo S., Tyree M.T., Vertivec M. (2000) Influence of the ectomycorrhizas formed by Tuber melanosporum Vitt. on hydraulic conductance and water relations of Quercus ilex L. seedlings, Ann. For. Sci. 57, 305-312, DOI 10.1051/forest:2000121.

Olivier J.M. (2000) Progress in the cultivation of truffles, in: Science and cultivation of edible fungi,Van Griensven (Ed.), Balkema, Rotterdam, The Netherlands, pp. 937-942.

Olivier J.M., Savignac J.C., Sourzat P. (1996) Truffe et Trufficulture, Fanlac (Ed.), Périgueux, France.

Ramsey F.L., Schafer D.W. (1996) The Statistical Sleuth, A Course in Methods of Data Analysis, Duxbury Press, Belmont, CA.

Rauscher T., Agerer R., Chevalier G. (1995) Ektomykorrhizen Von Tuber melanosporum, Tuber mesentericum und Tuber rufum (Tuberales) an Corylus avellana, Nova Hedwigia 61, 281-322.

Reyna S. (2000) Trufa, Truficultura y Selvicultura Trufera, MundiPrensa, Madrid.

Ricard J.M., Bergounoux F., Callot G., Chevalier G., Olivier J.M., Pargney J.C., Sourzat P. (2003) La Truffe, Guide technique de trufficulture, CTIFL, Paris.

Romieu M., Tabouret P. (1995) La Trufficulture : une des alternatives à la déprise agricole en Drôme, Forêts France 387, 20-22.

Sáez R., De Miguel A. (1995) Guía Práctica de Truficultura, I.T.G.A.S.A. (Ed.), Universidad de Navarra, Pamplona, Spain. 
Samils N., Olivera A., Danell E., Alexander S., Colinas C. (2003) Aportación de la truficultura al desarrollo socioeconómico, Vida Rural, 15 dic., pp. 54-60.

Shaw P.J.A., Lankey K., Jourdan A. (1996) Factors affecting yield of Tuber melanosporum in a Quercus ilex plantation in southern France, Mycol. Res. 100, 1176-1178.

Sourzat P. (1997) Guide Pratique de Trufficulture, Station d'expérimentations sur la truffe, Le Montat, France.

Sourzat P. (1999) Últimas tendencias en el cultivo de Tuber melanosporum, in: Colinas C., Fischer C. (Eds.), Cultivo de hongos comestibles micorrícicos, Publ. Univ. de Lleida, Lleida, Spain.
Sourzat P. (2002) Guide Practique de Trufficulture, Station d'expérimentation sur la truffe, Cahors-Le Montat, France.

Thornwaite C.W., Mather J.R. (1955) The Water Balance, Publications in Climatology 8, The Drexel Institute of Technology, Centerton, NJ, USA.

Treseder K.K. (2004) A meta-analysis of mycorrhizal responses to nitrogen, phosphorus, and atmospheric $\mathrm{CO}_{2}$ in field studies, New Phytologist 164, 1-9, DOI 10.1111/j.1469-8137.2004.01159.x.

Verlhac A., Giraud M., Leteinturie J. (1990) La Truffe, guide pratique, CTIFL (Ed.), Paris.

Weisberg S. (1980) Applied Linear Regression, John Wiley and Sons, New York.

To access this journal online: www.edpsciences.org 